\title{
KESAN KUALITAS DAN LOYALITAS MEREK TERHADAP KEPUTUSAN KONSUMEN MEMBELI PRODUK ZOYA
}

\section{PERCEIVED QUALITY AND BRAND LOYALTY TO CONSUMER DECISION TO BUY ZOYA PRODUCTS}

\author{
S. Riyanti1a \\ 1aProgram Studi Ekonomi Islam Fakultas Ekonomi Islam Universitas Djuanda, Jl. Tol Ciawi \\ No. 1, Kotak Pos 35 Bogor 16720
}

\begin{abstract}
This study aims to determine the quality and brand loyalty impression on consumers who buy products Zoya. This type of research uses descriptive quantitative approach and analyzed using the relative frequency distribution. The study population all consumers who use the product Zoya, sample of 40 respondents using simple random sampling technique. The results showed that kuallitas impression has a value of $57 \%$ and $54 \%$ of brand loyalty. Secondly it is capable of becoming one of the factors in the consumer's decision to buy the product Zoya.
\end{abstract}

Keywords: perceived of quality, brand loyalty, consumer decision

\begin{abstract}
ABSTRAK
Penelitian ini bertujuan untuk mengetahui kesan kualitas dan loyalitas merek pada konsumen yang membeli produk Zoya. Jenis penelitian menggunakan deskriptif dengan pendekatan kuantitatif dan dianalisis menggunakan distribusi frekuensi relatif. Populasi penelitian seluruh konsumen yang menggunakan produk Zoya, sampel berjumlah 40 responden melalui teknik simple random sampling. Hasil penelitian menunjukan bahwa kesan kuallitas mempunyai nilai 57\% dan loyalitas merek sebesar 54\%. Kedua hal tersebut mampu menjadi salah satu faktor keputusan konsumen dalam membeli produk Zoya.
\end{abstract}

Kata kunci: Kesan Kualitas, Loyalitas merek, keputusan konsumen

Riyanti, Sarah. 2017. Kesan Kualitas dan Loyalitas Merek terhadap Keputusan Konsumen Membeli Produk Zoya. Jurnal Syarikah2(2):1-16.

\section{PENDAHULUAN}

Perkembangan bisnis di Indonesia mengalami peningkatan, terbukti dengan ada banyaknya pengusaha yang muncul dan menghasilkan banyak produk, seperti produk makanan dan pakaian. Peningkatan ini memotivasi para pengusaha berinovasi, salah satu tampilan mode yang ikut melakukan inovasi yaitu pengusaha busana muslim.
Berkembangnya usaha busana muslim didukung oleh penduduk indonesia yang memeluk agama Islam dan total penduduk muslim sebanyak 234.693.997 jiwa (Indrawati, 2015: 303). Agama Islam mengajarkan umatnya agar menutup aurat seperti yang tercantum dalam Al-Quran surah Al-Ahzab ayat 59 berikut ini: yang artinya: "Hai Nabi, Katakanlah kepada istriistrimu, anak-anak perempuanmu dan istriistri orang mukmin: "Hendaklah mereka 
mengulurkan jilbabnya ke seluruh tubuh mereka". Yang demikian itu supaya mereka lebih mudah untuk dikenal, karena itu mereka tidak diganggu dan Allah adalah Maha Pengampun lagi Maha Penyayang". Ayat berikut menegaskan bahwa Allah SWT memerintahkan umat Islam untuk menutup aurat khususnya kaum wanita sehingga dijadikan landasan bagi umat Islam untuk menutup aurat. Hal tersebut menjadi potensi besar sekaligus peluang bagi pengusaha busana muslim. Tidak sedikit pengusaha busana muslim ternama di Indonesia, berikut beberapa pengusaha busana muslim ternama: Rabbani, Dannis, Azka, Almadani, Al Mia, Zoya, Shafira dan Nizar (Indrawati, 2015: 303).

Perusahaan Zoya adalah satu dari sekian merek busana muslim yang mengelola ekuitas merek dengan baik, terbukti dengan meraih penghargaan top brand dan best brand dua tahun berturutturut pada saat ini. Menurut Frontier Consulting Group, berikut top brand indeks Perusahaan Zoya mulai tahun 2014 sampai 2016:

\section{Tabel 1}

Top Brand Indeks Busana Muslim Tahun 2014-2016

\begin{tabular}{cccc}
\hline \multirow{2}{*}{ Merek } & \multicolumn{3}{c}{ Tahun } \\
\cline { 2 - 4 } & $\mathbf{2 0 1 4}$ & $\mathbf{2 0 1 5}$ & $\mathbf{2 0 1 6}$ \\
\hline Zoya & $3.9 \%$ & $8,0 \%$ & $25,3 \%$ \\
\hline Rabbani & $21,0 \%$ & $15,9 \%$ & $17,9 \%$ \\
\hline Dannis & $6,7 \%$ & $8,1 \%$ & $7,2 \%$ \\
\hline Lain-lain & $68,4 \%$ & $68,0 \%$ & $49,6 \%$ \\
\hline Sumber: www.topbrand-award.com & $(2014,2015$ \\
\hline
\end{tabular}

Berdasarkan tabel 1 dapat dilihat data statistik terhadap kekuatan merek atau Top Brand Indexs (TBI), indeks busana muslim Zoya setiap tahunnya memiliki peningkatan. Pencapaian yang diperoleh Zoya dengan menjadi Top Brand dan Best Brand Award tahun 2015 dan 2016 terjadi karena terbentuknya ekuitas merek atau brand equity yang baik. Pengelolaan manajemen brand equity yang bagus akan menciptakan dampak positif terhadap mereknya dan produk akan memiliki posisi yang bagus di pasar sehingga mempunyai daur hidup yang lebih lama dan menjadi indikator dalam mengambil putusan ketika pembelian (Rangkuti, 2002: 1).

Keputusan pembelian merupakan rencana konsumen maupun tindakan seorang konsumen yang lebih lanjut dan nyata untuk memperoleh produk tertentu. Umumnya konsumen melakukan pembelian terhadap barang memperhatikan beberapa alasan, diantaranya yaitu kualitas dan loyalitas yang berada pada sebuah merek, sehingga memberikan daya beli bagi seorang konsumen (Qurniawan, 2014: 381; Nujulia, 2013: 3)

\section{MATERI DAN METODE}

\section{Kesan kualitas (Perceived Quality)}

Kesan kualitas merupakan cerminan opini pelanggan terhadap seluruh keunggulan atau kualitas produk sesuai yang dibutuhkan, menurut Aaker 1996 dalam Rangkuti (2002: 41). Haryanto dalam Muzaqqi (2016: 27) ditemukan beberapa aspek yang menjadi dasar pendapat kualitas terhadap produk lain, diantaraya:

1. Kinerja merek

2. Keandalan

3. Pelayanan

4. Hasil akhir

5. Karakteristik produk

6. Kesesuaian spesifikasi

7. Bagian tambahan (feature)

Keuntungan yang diperoleh kesan kualitas berdasarkan pendapat Rangkuti (2004: 42):

1. Alasan membeli

Kesan kualitas terhadap merek menunjukkan argumen penting untuk dibeli. Hal ini membuat merek lainnya yang harus diperhitungkan dan selanjutnya memberikan pengaruh pada produk merek yang akan diambil.

2. Diferensiasi

3. Posisi pada dimensi kesan kualitas dimaksudkan sebagai karakteristik merek yang penting.

4. Harga optimum 
Keuntungan ini menawarkan pilihan untuk menetapkan harga optimum atau premium price.

5. Meningkatkan minat distributor

Keuntungan kelima ini memiliki pengertian penting untuk distributor, pedagang eceran serta beberapa akses lainnya, karena sangat membantu perluasan distribusi.

6. Perluasan sebuah merek

Kesan kualitas dapat dimanfaatkan dengan menggunakan berbagai metode perluasan merek, salah satunya kategori produk baru.

\section{Loyalitas merek (brand loyalty)}

Kesetiaaan konsumen atas merek tertentu, memperlihatkan tingkat keterkaitan suatu konsumen dengan produk dan dapat diartikan jika loyalitas pembeli akan suatu merek meningkat, maka dengan keuntungan yang diperoleh perusahaan juga ikut meningkat secara tidak langsung (Rangkuti, 2002: 61). Loyalitas memiliki lima tingkatan yang bisa disebut piramida loyalitas, diantaranya:

\section{Commited}

Tingkatan pertama disebut sebagai pelanggan setia, merek mempunyai suatu kebangggan dalam menggunakan merek tertentu.

2. Menyukai merek

Konsumen yang betul-betul menyukai merek, dengan begitu peran merek mempunyai posisi yang besar. Biasanya konsumen melandasi pada suatu gabungan seperti simbol dan pengalaman. Pembeli dijuluki sahabat merek pada tingkat ini.

3. Pembeli puas dengan beban peralihan Orang puas pada merek yang dipakai, tetapi konsumen memiliki biaya peralihan baik uang resiko maupun waktu. Sebagaimana usahanya untuk berpindah pada merek lainnya. Konsumen disebut sebagai statisfied buyer.

4. Pembeli puas atau berkarakter kebiasaan (tidak ada kendala beralih) Pembeli merasakan puas atau tidak kecewa atas produk yang digunakan.
Tipe konsumen yang demikian disebut tipe kebiasaan.

5. Berpindah-pindah, sadar akan perubahan harga (tidak ada loyalitas merek)

Pembeli tidak sedikitpun tertarik dengan suatu barang ataupun produk yang ditawarkan. Jenis konsumen ini biasanya berpindah-pindah dari merek yang satu ke merek lainnya atau disebut denga switcer atau price buyer.

Keputusan pembelian ialah aktivitas dari beberapa pilihan alternatif seorang konsumen untuk memilih hubungan alternatif keputusan antara konsumen dengan suatu produk yang konsumen butuhkan (Indrawati, 2015: 305; Nujulia, 2013: 3). Dalam pembelian suatu produk, terdapat tahap-tahap cara konsumen mengambil keputusan, keputusan pembelian menekankan bahwa proses untuk membeli bermuka sebelum pembelia dan berakibat jauh setelah pembelian, berikut beberapa proses sebelum melaksanakan transaksi (Pradipta, 2016: 141):

1. Pengenalan masalah

2. Pencarian informasi

3. Evaluasi alternatif

4. Keputusan pembelian

5. Perilaku pasca pembelian

\section{Jenis Penelitian}

Penelitian yang dipakai adalah deskriptif melalui pendekatan kuantitatif. Penelitian kuantitatif adalah cara yang dipakai untuk menaganlisis populasi dan sampel dengan mengumpulkan data instrumen, data yang dianalisis bersifat kuantitatif/statistik dan untuk melakukan suatu uji hipotesis yang telah dipilih (Sugiyono, 2014: 8, 12). Penelitian deskriptif kuantitatif bertujuan untuk melihat keputusan konsumen membeli produk Zoya dengan melihat kesan kualitas dan loyalitas.

\section{Populasi dan Sampel}

Populasi adalah daerah atau sekumpulan yang meliputi dari obyek atau subyek dan mempunyai kualitas serta ciri tertentu yang sudah ditentukan oleh 
peneliti untuk dipelajari, selanjutnya akan ditarik kesimpulan (Sugiyono, 2014: 80). Populasi yang digunakan yaitu semua konsumen yang mengenakan produk Zoya. Sampel merupakan komponen dari kuantitas populasi yang mencirikan karakteristik tersebut (Sugiyono, 2014: 81), dikarenakan jumlah populasi tidak diketahui secara jelas, maka pengambilan jumlah sampel ditetapkan dengan rumus Josep F. Hair, dimana ukuran sampel penelitian dari populasi tersebut dapat dijelaskan dengan rumus yaitu 15 atau 20 kali variabel bebas, sehingga didapatkan hasilnya yaitu:

$20 \times 2$ (jumlah varibal bebas) $=40$ (Purnama: 2015: 40).

\section{Teknik Sampling}

Margono (2004: 125) menyebutkan bahwa teknik sampling adalah trik yang digunakan untuk membetulkan sampel agar ukuran dan jumlah suatu sampel sesuai dengan data dengan memperhatikan penyebaran populasi dan sifat-sifat sampel yang diperoleh sesuai. Teknik sampling adalah simple random sampling yang merupakan cara pemilihan sampel dimana anggota dari populasi dipilih satu persatu secara random dan jika sudah terpilih, tidak dapat dipilih kembali (Anam, 2014: 42).

\section{Jenis dan Sumber}

Data primer dan data sekuner merupakan jenis data yang akan digunakan. Data primer adalah bahan pokok dalam penelitian dan menjadi sumber (Arikunto, 2010: 145). Data primer yang digunakan ialah kuesioner dan wawancara, sedangkan data Sekunder sebagai pendukung dan penunjang dalam penelitian (Arikunto, 2010: 157) data primer diperoleh dari jurnal, buku, web dan bahan pustaka lainnya yang mempunyai keterikatan dengan penelitian.

\section{Teknik Pengumpulan Data}

Teknik mengumpulkan data adalah metode penting, karena berguna untuk menghasilkan sebuah data yang akan dianalisis, apabila tidak mengetahui data, maka seseorang tidak dapat melakukan penelitian dengan baik (Sugiyono, 2014: 224). Adapun penggunaan teknik pengumpulan melalui kuesioner dan wawancara. Kuesioner adalah upaya yang dilaksanakan dengan memberikan beberapa pernyataan dan pertanyaan kepada pemberita untuk dijawabnya secara tertulis dan digunakan agar mengetahui alasan konsumen mengambill keputusan untuk memilih produk Zoya. Wawancara ialah pertemuan dua atau lebih pihak untuk saling menukarkan ide atau informasi, sehingga dapat menghasilkan makna yang terperinci dalam tema khusus dan tujuan penelitian bermaksud untuk mencari keterangan secara mendalam mengenai keputusan seorang konsumen menggunakan Zoya.

\section{Teknik Analisis Data}

Usaha untuk mendapatkan kesimpulan dengan mengolah dengan mengolah data tersebut menjadi sekumpulan yang bisa dikelola, menggali dan menetapkan sebuah pola dan menemukan hal penting dan bisa dipelajari dan bisa diceritakan pada pihak lain disebut analisis data (Moleong, 2013: 248). Karya ilmiah ini dijalankan dengan teknik yang akan dilalui, berikut tahaptahapnya :

1. Uji Reliabilitas dan Uji Validitas

Alat untuk mengukur kuesioner yang menjadi indikator dari variabel merupakan pengertian dari reliabel, untuk menentukan reliabel atau tidak reliabel kuesioner dengan menggunakan alpha cronbach. Suatu kuesioner reliabel jika cronbach's alpha $>0,60$ dan tidak reliabel jika sama dengan atau dibawah 0,60 (Sunyoto, 2014: 125). Uji validitas dipakai untuk menimbang valid tidaknya suatu kuesioner dan dikatakan valid jika jawaban kuesioner responden dapat mengemukakan hal yang bisa dihitung oleh angket tersebut. Untuk mengukur angket dalam penelitian menggunakan signifikan pada koefisien antar butir tanya, setiap atribut terhadap rataratanya dengan hasil perhitungan 
dalam komputer dengan SPSS(Sunyoto, 2014: 125).

2. Skala likert

Skala yang memberikan kegunaan dalam mengukur pendapat, sikap, dan persepsi selompok atau seseorang tentang fenomena sosial, maka variabel yang telah diukur dijelaskan menjadi suatu indikator variabel, selanjutnya indikator tersebut dijelaskan sebagai tolak ukur untuk menyusun item-item instrumen, baik berupa pertayaan maupun pernyataan. Terdapat lima preferensi jawaban, dengan masingmasing skor 1-5 pada rincian berikut (Sugiyono, 2013: 136):

Tabel 2 Skor Skala Likert

\begin{tabular}{|c|c|}
\hline Krtiteria & Nilai \\
\hline Sangat Setuju (SS) & 5 \\
Setuju (S) & 4 \\
Kurang Setuju (KS) & 3 \\
Tidak Setuju (TS) & 2 \\
Sangat Tidak Setuju (STS) & 1 \\
\hline
\end{tabular}

Sumber: Sugiyono 2013

3. Analisis Data

Analisis deskriptif dan distribusi frekuensi relatif ialah analisis data yang diperlukan dalam karya ilmiah ini. Deskriptif analisis yaitu menggambarkan kondisi dengan keadaan yang sesuai kemudian dianalisis. Distribusi frekuensi relatif digunakan untuk mempermudah dalam menganalisis data. Distribusi frekunsi dimana frekuensinya diperlihatkan dengan bilangan bilangan tertentu yang berupa persentase dan total keseluruhan frekuensinya sama dengan satu atau seratus persen (setiawan, 2013: 7).

\section{HASIL DAN PEMBAHASAN}

\section{Sejarah Singkat Zoya}

Zoya berdiri tahun 2005 selaku perusahaan busana musilm, sekaligus menjadi alternatif bagi konsumen yang mencari busana muslim berkualitas, up-todate keterjangkauan harga. Shafco Enterprise ialah satu dari beberapa lini bisnis dari Zoya, satu perusahaan yang bergelut dalam bidang busana muslim dari tahun 1989 dan berkantor pusat di Bandung Indonesia. Nama Zoya merupakan nama feminim yang digunakan di Ukranina dan Rusia, diambil dari bahasa Yunani kuno yang mempunyai arti "kehidupan", dalam bahasa India "bersinar", bahasa Arab yang berarti "menyenangkan" dan "peduli". Logo Zoya berwarna hijau melambangkan ketenangan, kehidupan, kesegaran dan pertumbuhan. Warna coklat artinya kenyamanan dan daya tahan yang melambangkan tanah dan bumi. Brand Philosophy perusahaan Zoya dilambangkan Light and color. Zoya menunjukkan koleksi dengan karakter easy to wear, easy to match, ringan serta lengkap dengan warna dan desain. Dalam rangka ekspansi bisnisnya, Zoya juga mengembangkan usaha dengan menambah lini bisnis yaitu membuka berbagai jenis kebutuhan perempuan seperti: Zoya Home, Zoya Jeans dan Zoya Cosmetics.

Visi dan Misi Perusahaan Zoya

Visi

Menjadi referensi utama bagi para muslimah dalam berbusana hijab yang fashionable.

Misi

1. Memberikan inspirasi agar muslimah selalu berhijab dengan stylish.

2. Memberi solusi kecantikan bagi wanita muslimah.

3. Menciptakan style dengan inovasiinovasi busana muslim terkini.

\section{Produk Zoya}

\section{Zoya Fashion}

Zoya Fashion menjadikan kerudung sebagai salah-satu produk unggulan. Namun, selain itu Zoya Fashion juga menyediakan aksesoris, busana hingga perlengkapan peralatan ibadah bagi para konsumen. Model menarik juga anggun tersedia di outlet Zoya. Sehingga, berbagai produk menjadi pilihan sesuai untuk mengisi hari customer dalam situasi apapun. 
2. Zoya Home

Zoya Home merupakan referensi bagi customer saat aktivitas sehari-sehari baik di dalam maupun di luar rumah. Agar tetap nyaman dan stylish, produk Zoya Homes di buat dengan bahan adem dan lembut dengan model simpel dan menarik sehingga membuat aktivitas konsumen sehari-hari .

3. Zoya Jeans

Zoya jeans dibuat untuk costumer yang senang dengan produk berbahan dasar jeans, baik untuk yang bergaya kasual ataupun santai, Zoya jeans menyediakan koleksi seperti koleksi atasan yang meliputi outerwear, tunik, shirt dan dress hingga koleksi bawahan seperti beragam rok panjang dan celana.

4. Zoya Cosmetics

Zoya Cosmetics merupakan pelengkap kebutuhan customer akan produkproduk kecantikan seperti peralatan make-up: lipstik, blush on, bedak, eye brow, BB cream, eye shadow, maskara dan lip balm, juga perawatan untuk wajah dan tubuh seperti body mist, facial wash dan masker. Dengan hadirnya Zoya Cosmetics sehingga membantu muslimah mempercantik wajahnya setiap hari.

\section{Profil Pelanggan}

1. Demografis

Jenis kelamin : Pria dan wanita.

Kelas Sosial : menengah.

Usia : 18 tahun ke atas

2. Psikografi

a. Bergaya hidup modern.

b. Sesuai fashion terkini.

c. Senang bersosialisasi

3. Brand Ambasador

Indah Nevertari, Eriska Rein, Lula Kamal dan Soraya Larasati adalah nama-nama yang termasuk brand ambassador produk Zoya karena mereka dianggap mengeluarkan aura cantiknya muslimah Indonesia.

4. Sponsored Programs

Sejumlah program film seperti "Eat Bulaga Indonesia", "Assalamualaikum
Beijing", "Mak Ijah Ingin ke Mekah", "Kukejar Cinta ke Negeri Cina", "Hijrah Cinta", dan "The Comment" telah mempercayai Zoya sebagai penopang busana dan make-up.

Uji Validitas dan Uji Realiabilitas

Reliabilitas dilakukan melalui cara melihat koefisien Cronbach Alpha yang dapat diterangkan sebagai rangkaian positif pertanyaan satu dan yang lainnya. Suatu alat penelitian reliabel jika dinyatakan memiliki Alpha yang berkisar antara 0,60 0,70. Dasar pengambilan keputusan jika:

Cronbach Alpha $>0,60 \rightarrow$ Construct Reliable Cronbach Alpha $<0,60 \rightarrow$ Construct Not Reliable (Siti, 2016: 75)

Hasil perhitungan SPSS 22 uji reliabilitas :

\section{Tabel 3}

Reliability Statistick

\begin{tabular}{|c|c|}
\hline Cronbach's Alpha & N of Item \\
\hline, 984 & 17 \\
\hline
\end{tabular}

Sumber: Hasil penelitian (data diolah) 2017

Pada tabel 3 hasil pengujian reliabilitas membuktikan bahwa perolehan nilai statistik sebesar 0,984. Nilai tersebut menerangkan bahwa untuk pengajuan 17 pertanyaan pada konsumen Zoya sebagai responden adalah reliabel, karena sesuai asas pengambilan keputusan 0,984 >0,60. Untuk uji validitas ditentukan berdasarkan koefisien korelasi ( $r$ ), dimana apabila $r_{\text {hitung }}$ $>r_{\text {tabel, maka instrumen tes yang }}$ diujicobakan tersebut dapat dinyatakan valid. Tingkat validitas diketahui memberikan petunjuk keadaan korelasi tiap skor item (nilai $r_{\text {hitung}}$ ) dibandingkan nilai $r_{\text {tabel }}$ yang diperoleh lewat program SPSS versi 22. Dengan penggunaan distribusi tabel $r$ berdasarkan $\alpha=0,05$ telah didapat $r_{\text {tabel }}=0,321$. Sesuai perolehan data menunjukan nilai validitas pernyataan nomor 1 (KK1) sampai dengan pertanyaan nomor 17 (PKK7) berada diatas nilai 0,321 . Sehingga semua pernyataan valid.

\section{Karakteristik Responden}

Responden yang dijadikan sampel adalah konsumen yang menggunakan produk muslim Zoya dan ditentukan 
menggunakan teknik analisis random sampling dimana penentuan sampel dipilih satu-persatu secara tidak beraturan dan jika seseorang sudah terpilih maka tidak dipilih kembali. Karakteristik responden dikategorikan menjadi jenis kelamin, usia, pekerjaan dan pendapatan.

Berdasarkan 40 responden yang sudah mengisi kuesioner, responden perempuan menempati urutan tertinggi dengan nilai persentase sebesar $100 \%$ sedangkan lakilaki persentasenya bejumlah $0 \%$. Zoya menyediakan produk untuk perempuan dan laki-laki, tetapi mayoritas produk tersebut disediakan untuk perempuan, mulai dari fashion (gamis, rok, kerudung, atasan, celana panjang dan lain-lain), kosmetik sampai dengan peralatan ibadah seperti sajadah dan mukena. Selain alasan tersebut, rata-rata konsumen yang mengisi pertanyaan kuesioner adalah santri dan guru-guru di daerah Bogor yang memakai kerudung merek Zoya. Selain produk yang diperutukan untuk perempuan, Zoya juga menyediakan produk untuk laki-laki diantaranya yaitu: koko, kemko (kemeja koko), sorban, celana bahan dan peralatan ibadah, bukan berarti laki-laki tidak menggunaan Zoya, akan tetapi kebanyakan mereka membeli produk Zoya untuk diberikan sebagai hadiah.

Usia Responden dari 40 konsumen Zoya terdapat 22 orang (55\%) berumur 18 sampai 25 tahun, umur 26 hingga 30, ada 12 orang $(30 \%)$ dan 6 orang $(15 \%)$ yang usianya sudah lebih dari 30 tahun. Sehingga dapat karakteristik responden jika dibaca dari umur yang paling dominan adalah umur 18 hingga 25 tahun dengan kuantitas persentase sebesar 55\%. Responden yang rata-rata menginjak 18 sampai dengan 25 tahun adalah usia remaja menginjak dewasa, dimana seseorang merasa ingin tampil beda dengan yang lain, sesuai dengan produk Zoya pada psikologi profil pelanggan dimana fasion mengikuti terkini dan modern. Berbeda dengan orang yang telah berumur 30 tahun keatas, mereka tidak begitu memperhatikan fashion dan cenderung cuek terhadap penampilan. Demikian hal itu mengartikan bahwa bukan tidak terdapat orang berusia $>30$ pada tahun memperhatikan gaya dan fashion, melainkan jumlahnya tidak banyak.

Jenis pekerjaan responden dari 40 sampel, terdapat 7 orang $(17,5 \%)$ bekerja sebagai wiraswasta, 20 orang (50\%) bekerja sebagai mahasiswa/pelajar dan 13 orang $(32,5 \%)$ bekerja sebagai pekerja lainnya, pekerja yang memilih lainnya antara lain bekerja sebagai ibu rumah tangga, pensiunan dan guru-guru dengan berstatus honorer. Hasil data memperlihatkan bahwa konsumen yang berprofesi sebagai mahasiswa atau pelajar lebih mendominasi dengan nilai persentase sebesar 50\%. Semua itu dikarenakan oleh mahasiswa yang mengisi kuesioner, ustadzah dan santri di daerah Bogor. Pekerjaan lainnya yang mempunyai nilai persentase besar lebih dari 30\% adalah pekerja lainnya, dimana IRT lebih mendominasi karena kerudung Zoya mempunyai bahan yang simpel dan ringan sehingga nyaman dipakai bagi orang yang aktif bekerja seperti ibu rumah tangga.

Pendapatan responden produk Zoya dari 40 orang, terdapat 20 informan (50\%) memiliki pendapatan $\leq$ Rp. 1.000.000,00,-, 13 orang $(32,5 \%)$ memiliki pendapatan Rp. 1.000.000 - Rp. 3.000.000,- dan 7 orang $(17,5 \%)$ memiliki pendapatan $\geq$ Rp. 3.000.000,00,-. Dari hasil tersebut menggambarkan mengenai karakteristik konsumen yang memakai poduk Zoya berdasarkan pendapatannya, dimana konsumen yang berpendapatan dibawah $\leq$ Rp. 1.000.000,00,- mendominasi dengan nilai persentse sebesar 50\%. Hal ini bersangkutan dengan pencapaian data pada penelitian yang menjelaskan mengenai pekerjaan responden, hasilnya yaitu mahasiswa dan pekerjaan lain (ibu rumah tangga) yang mendominasi karena tidak berpenghasilan tetap serta masih dibiayai oleh orang lain.

Selanjutnya hasil perolehan data tentang tanggapan responden melalui 
proses analisis skala likert, lebih diperinci sebagai berikut:

Responden beranggapan material yang digunakan produk Zoya berkualitas, anggapan sangat setuju totalnya yaitu 14 responden dengan pembagian $(40,7 \%)$, berangggapan setuju berjumlah 24 orang dengan bagian $(55,8 \%)$ dan responden kurang setuju berjumlah 2 orang dengan persentase $(3,5 \%)$. Hasil diperoleh angka kriteria penafsiran sebesar $M=4,3$. Dari perolehan data tersebut memperlihatan rata-rata responden "setuju" dengan material produk Zoya yang berkualitas.

Pandangan konsumen terkait pernyataan produk Zoya mempunyai motif yang menarik, yaitu konsumen yang setuju berjumlah 26 orang dengan bagian $(60,5 \%)$, sangat setuju 13 responden dengan pembagian $(37,8 \%)$ dan kurang setuju berjumlah 1 orang dengan bagian (1,7\%). Dari data tersebut angka kriteria penafsiran yang diperoleh sebesar $M=4,3$, maka umunya responden "setuju" dengan motif-motif yang ada diproduk Zoya menarik.

Pendapat responden tentang warna kerudung pada produk Zoya beragam, yaitu kurang setuju terdapat 1 orang responden dengan pembagian $(3,4 \%)$, sangat setuju 18 responden dengan persentase $(51,1 \%)$ dan setuju 20 orang responden dengan bagian $(45,5 \%)$. Diperoleh $M=4,4$. Hasil pemaparan menerangkan rata-rata konsumen "sangat setuju" dengan warna kerudung Zoya sangat beragam.

Penilaian mengenai pelayanan pada saat konsumen membeli produk Zoya memuaskan, yang beranggapan tidak setuju berjumlah 2 responden dengan persentase $(2,62 \%)$, setuju 29 responden persentasenya $(75,82 \%)$, sangat setuju 3 responden pembagiannya $(9,8 \%)$ dan total responden kurang setuju berjumlah 6 orang dengan peersentasenya adalah $(11,76 \%)$, maka $M=3,83$. Dari perolehan skala likert menunjukkan bahwa umumnya responden "setuju" dengan pelayanan yang diberikan pada konsumen memuaskan.
Tanggapan responden terhadap pernyataan Zoya yang memiliki ciri khas pada busana muslim, yang merespon sangat setuju berjumlah 12 responden (35,93\%), setuju 24 responden (57,48\%), kurang setuju 3 orang dengan pembagian (5,39\%) dan responden kurang setuju 1 orang dengan pembegiannya $(1,2 \%)$., diperoleh angka kriteria penafsiran sebesar $\mathrm{M}=4,2$. Hasil berikut menegaskan bahwa rata-rata beranggapan "setuju" dengan busana muslim Zoya mempunyai ciri khas.

Anggapan responden menyangkut pernyataan produk Zoya lebih disukai dibanding dengan produk buatan lain. Persentase yang merespon sangat setuju berjumlah 3 responden (10,87\%), setuju 17 responden $(46,38 \%)$, kurang setuju 16 orang $(36,96 \%)$ dan tanggapan 4 responden tidak setuju (5,79\%), maka angka kriteria penafsiran sebesar $\mathrm{M}=3,45$. Dari hasil perhitungannya menegaskan rata-rata konsumen "setuju" bahwa konsumen lebih menyukai Zoya dibanding produk busana yang lain.

Opini konsumen perihal pernyataan saya akan membeli produk Zoya dikemudian hari yaitu sangat setuju berjumlah 4 responden $(13,25 \%)$, setuju 26 responden $(68,87 \%)$, tidak setuju 3 orang $(3,97 \%)$ dan 7 orang kurang setuju $(13,91 \%)$ dan $M=3,77$. Hasil perhitungan tersebut mendeskripsikan rata-rata responden "setuju" bahwa dikemudian hari konsumen akan menjalankan pembelian kembali produk Zoya.

Respon konsumen perihal pernyataan saya tidak akan beralih kepada selain produk Zoya, persentase yang berpendapat sangat setuju berjumlah 2 responden (7,6\%), tidak setuju 1 orang (1,53\%), 29 responden kurang setuju $(66,43 \%)$ dan total 8 orang responden setuju pembagiannya $(24,44 \%)$ dan sebesar $M=$ 3,27. Hasil perhitungannya memperlihatkan rata-rata responden "kurang setuju" jika mereka tidak akan berpindah kepada produk selain Zoya.

Tanggapan konsumen responden mengenai pernyataan saya akan 
menganjurkan orang lain untuk menggunakan produk Zoya, persentase yang beranggapan setuju berjumlah 25 responden $(65,36 \%)$, persentase sangat setuju 5 responden (16,34\%), 2 responden tidak setuju $(2,62 \%)$ dan tanggapan 8 responden kurang setuju (15,68\%), sehingga nilai $M=3,8$. Dari keterangan tersebut menggambarkan rata-rata konsumen "setuju" mereka akan merekomendasikan yang lainnya untuk ikut menggunakan produk Zoya.

Tanggapan konsumen terhadap pernyataan saya bersedia membayar mahal untuk produk Zoya, persentase beranggapan sangat setuju berjumlah 3 orang informan (1145\%), setuju 11 responden (33,59\%), 21 responden kurang setuju (48,09\%), tidak setuju 4 responden $(6,11 \%)$ dan total responden sebanyak 1 orang $(0,76 \%)$ sangat tidak setuju, maka dihasilkan $M=3,27$. Dari hasil di atas menerangkan rata-rata responden "kurang setuju” apabila informan sanggup membayar mahal produk Zoya.

Respon konsumen mengenai pernyataan saya mengenali masalah sebelum membeli produk Zoya, yaitu persentase sangat setuju berjumlah 3 narasumber $(11,11 \%)$, sangat tidak setuju hanya 1 orang $(0,74 \%), 17$ orang memilih kurang setuju $(37,79 \%)$, tanggapan 15 responden setuju $(44,44 \%)$ dan total 4 orang tidak setuju (5,92\%) jadi didapat nilai $\mathrm{M}=3,37$. Dari keterangan yang di atas menggambarkan rata-rata konsumen "setuju" dengan anggapan mereka selalu mengenali masalah terlebih dahulu sebelum menentukan produk Zoya dibeli.

Opini responden mengenai pernyataan saya mencari informasi terlebih dahulu sebelum melakukan pembelian terhadap produk Zoya, persentase 1 orang responden yang sangat tak setuju $(1,31 \%)$, setuju 24 responden $(62,74 \%), 5$ informan sangat setuju $(16,34 \%)$ dan beranggapan kurang setuju 10 responden $(19,61 \%)$. Maka skala likert diperoleh angka kriteria penafsiran sebesar $M=3,82$. Dari informasi tersebut menegaskan rata-rata responden "setuju" bahwa mereka sebelumnya mencari informasi lalu melakukan pembelian.

Anggapan responden terhadap pernyataan saya mengenal produk Zoya dari media massa, persentase yang berangggapan tidak setuju berjumlah 4 responden (6,06\%), 21 responden kurang setuju $(47,73 \%)$, setuju 14 responden $(42,42 \%)$ dan total informan sangat setuju berjumlah 1 orang $(3,79 \%)$ dan nilai $\mathrm{M}=$ 3,3. Hasil perhitungannya memberi gambaran akan responden yang rata-rata "kurang setuju" jika responden mengenal produk Zoya melalui media massa.

Tanggapan konsumen tentang pernyataan saya membandingkan kualitas busana muslim Zoya dengan yang produk lain sebelum mengambil keputusan pembelian, persentase yang merespon sangat setuju berjumlah 2 orang $(7,41 \%), 1$ sangat tidak setuju $(0,74 \%), 16$ orang kurang setuju (35,55\%), setuju 17 responden $(50,37 \%)$ dan total 4 orang responden tidak setuju (5,93\%). Hasil perhitungan penafsiran sebesar $\mathrm{M}=3,37$. Dari angka tersebut menegaskan rata-rata beranggapan "setuju" konsumen membandingkan kualitas sebelum membeli produk Zoya.

Pandangan konsumen perihal mempertimbangkan harga Zoya sebelum melakukan pembelian, yang merespon kurang setuju berjumlah 9 orang dengan pembagian $(17,09 \%)$, pemberita sangat setuju 7 orang $(22,15 \%)$ dan sebanyak 24 pemberita yang setuju $(60,76 \%)$. Hasil yang diperoleh sebesar $M=3,95$. Hasil tersebut membuktikan bahwa umunya konsumen "setuju" mengenai anggapan konsumen mempertimbangkan harga Zoya sebelum melakukan pembelian.

Penilaian responden terkait pernyataan saya membeli produk Zoya setelah memperoleh informasi yang cukup, persentase yang beranggapan kurang setuju berjumlah 20 orang dengan bagian $(46,87 \%)$, tidak setuju 6 responden $(11,72 \%), 3$ responden sangat setuju (9,38\%), 10 responden setuju $(31,25 \%)$ 
dan 1 orang sangat tidak setuju $(0,78 \%)$ dan mendapatkan nilai $M=3,2$ sehingga menegaskan rata-rata "kurang setuju" bahwa responden membeli produk Zoya setelah mendapatkan sumber informasi yang cukup.

Pendapat responden menyangkut pernyataan saya memutuskan membeli produk Zoya karena sesuai dengan apa yang diharapkan. Persentase yang berpendapat setuju berjumlah 24 orang $(57,14 \%)$, informan 12 sangat setuju $(35,72 \%)$ dan kurang setuju 4 responden $(7,14 \%)$ sehingga nilai $M=4,2$. Hasil perhitungan tersebut memperlihatkan rata-rata responden "setuju" bahwa produk Zoya setara dengan yang diinginkan konsumen.

\section{Kesan konsumen akan Kualitas dan loyalitas merek terhadap pembelian produk Zoya}

Data yang diambil melalui instrumen berupa pernyataan sebanyak 17 butir dalam bentuk lima skala dengan skor urutan dari mulai satu hingga lima yang kemudian dianalisa dan dikelompokkan menggunakan distribusi frekuensi relatif guna memudahkan membaca data secara tepat berkaitan dengan kesan loyalitas dan kualitas sebuah merek Zoya. Berikut hasil analisanya:

Berlandaskan distribusi frekuensi, didapatkan 0,6 (60\%) respoden setuju, 0,35 (35\%) informan sangat setuju, informan kurang setuju 0,05 (5\%), tidak setuju (0\%) dan informan (0\%) sangat tidak setuju. Sehingga terlihat kebanyakan orang setuju jika material yang digunakan produk Zoya berkualitas dengan persentase $60 \%$. Perusahaan Zoya menggunakan material produk yang berkualitas. Material Zoya dibuat dari bahan kain impor berkualitas, bahan kain tersebut diantaranya: thai silk, chiffon, tissue, lycra dan lain-lain. Diantara bahan kerudung yang disebutkan, kain lycra import yang sangat halus dan nyaman menjadi andalan pihak Zoya dari tahun 2007 hingga saat ini. Zoya sengaja mendatangkan kain lycra dengan kualitas terbaik, meskipun sudah cukup banyak brand kerudung lain yang mengatas namakan bahan lycra namun produk Zoya tetap khas dan lain dari produk lainnya. Selain itu, Zoya mengenakan bahan dasar yang tersertifikasi halal dan sesuai UU, sehingga memberikan kenyamanan dan memberi rasa aman kepada konsumen yang menggunakannya. Hal berikut merupakan argumen yang memilih setuju jika bahan produk Zoya berkualitas. Sebanyak 35\% responden kurang setuju dengan pernyataan yang diberikan, konsumen tersebut dinamakan tipe kebiasaan atau habitual buyer dimana klien merasa puas atau minimal tidak kecewa, akan tetapi apabila ada produk lain maka akan segera mencoba dan berganti ke produk tersebut, begitu seterusnya.

Selanjutnya dihasilkan 0,02 (2\%) responden kurang setuju, 0,65 (65\%) setuju, sangat setuju 0,33 (33\%), pelapor sangat tidak setuju (0\%) dan (0\%) tidak setuju. Sehingga disimpulkan pelanggan setuju bahwa motif yang tampak pada kerudung Zoya menarik. Seperti motif yang dikerjakan oleh desainer Ivan Gunawan yang meluncurkan hijab dengan tema "Heritage Beauty" dan termotivasi oleh Indonesia yang akan kaya budaya, yakni kebudayaan tradisional mulai Sabang sampai Merauke. Beberapa yang diambil adalah songket, tenun dan batik. Ivan mengambil dari corak kultur tradisional ditambahkan dengan motif garis. Berdasarkan hal berikut, pemakai merasa bahwa motif Zoya unik, beragam dan berbeda dengan produk yang lain. Selain itu, sesuai dengan misi perusahaan Zoya yaitu memberikan gagasan kepada muslimah agar mengenakan hijab dengan stylish, PT. Shafco Enterprice ini berinovasi dan sangat memperhatikan bagaimana sebuah produk Zoya harus terus tumbuh, dengan mengangkat produk baru yang menciptakan model dan ornamen yang indah setiap minggunya. Motif yang tergambar pada kerudung Zoya jika dilihat sekilas memang sedikit lebih ramai, namun apabila diperhatikan dengan benar 
motifnya berbentuk sama dan sederhana, sehingga akan terlihat indah saat digunakan.

Hasil perhitungan data didapatkan 0,5 (50\%) responden setuju, 0,45 (45\%) responden sangat setuju, informan 0,05 kurang setuju (5\%), tidak setuju (0\%) dan $(0 \%)$ sangat tidak setuju. Perhitungan tersebut menegaskan bahwa responden setuju warna kerudung Zoya beragam dengan persentase $50 \%$. Kerudung Zoya didesign dengan rupa yang tidak membosankan dan memiliki warna kerudung yang bervariasi, tidak hanya warna gelap dan warna cerah Zoya juga menghadirkan warna yang lembut contohnya warna pastel yang sedang banyak digemari oleh sebagian besar perempuan terutama kalangan remaja. Selain itu, kombinasi pada kerudung mempunyai macam-macam warna cantik dan seimbang dengan warna busana yang akan dikenakan. Hasil tersebut sejalan dengan penelitian yang dilaksanakan Devi Indrawati yang berjudul "pengaruh citra merek dan gaya hidup hedonis terhadap keputusan pembelian jilbab Zoya" bahwa responden setuju produk Zoya memiliki ragam pilihan warna.

Berdasarkan analisis data didapatkan 0,5 (50\%) konsumen setuju, 0,07 (7\%) sangat setuju, 0,15 (15\%)informan yang kurang setuju, tidak setuju 0,03 (3\%) dan $(0 \%)$ sangat tidak setuju. Data tersebut menunjukkan dominasi setuju menurut mereka pelayanan pada saat membeli produk Zoya memuaskan dengan persentase 50\%. Mereka menyebutkan pelayanan yang disajikan oleh pihak Zoya memberi kesan yang nyaman sehingga konsumen lebih senang belanja produk Zoya dibanding produ lain. Selain itu, perusahaan Zoya memuaskan pelanggan dengan menjual produknya melalui online dengan alamat store.zoya.co.id sehingga konsumen tidak harus mengunjungi outlet langsung. Zoya juga melakukan kerja sama dengan toko online yang terkenal di Indonesia seperti: lazada, blibli.com, buka lapak.com, toko jilbabflowidea.com dan sebagainya. Salah satu layanan yang tersedia yaitu sistem dibayar di tempat transaksi atau COD (cash on delivery) dimana pembayaran dilaksanakan ketika barang telah ada ditangan konsumen. Usaha tersebut dilakukan perusahaan agar konsumen mudah berbelanja.

Diperoleh data 0,6 (60\%) responden setuju, 0,3 (30\%) sangat setuju, 0,07 (7\%) kurang setuju, tidak setuju 0,03 (3\%) dan $(0 \%)$ pelapor sangat tidak setuju. Data tersebut menegaskan bahwa anggapan setuju mendominasi berkenaan dengan produk Zoya yang memiliki kekhususan dengan persentase $60 \%$. Karena kualitas yang baik dan corak unik yang beragam membuat produk Zoya dikenal mempunyai kekhususan tersendiri, khususnya pada hijab square yang diproduksi. Selain itu lambang atau logo Zoya yang berwarna hijau dan coklat memudahkan konsumen untuk mengingat merek Zoya. Sama halnya dengan piramida kesadaran merek dimana konsumen tersebut dinamakan (top of mine) atau puncak pikiran, seorang konsumen mengenal sebuah merek tanpa bantuan sehingga merek dijadikan kepentingan dan pilihan utama konsumen (Rangkuti, 2002: 40).

Sesuai dengan analisis data diperoleh $0,07(7 \%)$ narasumber sangat setuju, 0,4 (40\%) kurang setuju, setuju 0,43 (43\%), tidak setuju $0,1 \quad(10 \%)$ dan (0\%) narasumber sangat tidak setuju. Terlihat jelas bahwa responden setuju terkait produk Zoya lebih disukai dan menjadi bandingan produk lainnya sebanyak 43\%. Sebagian responden mempunyai alasan bahwa Zoya memiliki kelebihan diantaranya yaitu bahan yang mudah diatur, warna yang disediakan beragam dengan pilihan model kekinian namun masih bisa tetap syar'i. Selain itu responden merasa bangga dan mempunyai kepuasan tersendiri jika mereka menggunakan produk Zoya, karena Zoya bermitra dengan fashion designer yang sangat terampil dan terkenal yaitu, artis Ivan Gunawan yang berkontribusi dalam 
pembuatan pakaian dan kerudung muslim Zoya, sehingga menjadi pembeda dengan produk busana muslim lain. Responden yang berpendapat kurang setuju perihal pernyataan bahwa Zoya lebih mereka sukai menduduki peringkat kedua dengan nilai persentase $40 \%$, mereka menggunakan sejumlah produk busana muslim lain dan merasa bahagia dengan produk tersebut.

Dihasilkan data $0,1(10 \%)$ pemberita sangat setuju, 0,65 (65\%) pemberita setuju, kurang setuju 0,18 (18\%), sangat tidak setuju (0\%) dan tidak setuju 0,07 (7\%). Sehingga disimpulkan pemberita setuju akan membeli produk Zoya dikemudian hari sebesar 65\%. Kualitas dan kekuatan merek yang dimiliki produk Zoya membuat sebagian konsumen akan terus membeli lagi. Meskipun merek-merek baru bermunculan mereka tetap menjadi pelanggan setia, seorang konsumen tersebut sudah mempercayakan Zoya sebagai busana muslim yang akan terus digunakan. Konsumen yang dimaksud dinamakan dengan sahabat merek dimana mereka sudah benar-benar menyukai suatu merek karena disebabkan oleh suatu asosiasi seperti simbol atau pengalaman memakai produk (Rangkuti, 2002: 16).

Sesuai hasil analisis 0,2 (20\%) responden kurang setuju, 0,72 (72\%) setuju, sangat setuju 0,05 (5\%), narasumber yang sangat tidak setuju $(0 \%)$ dan 0,03 (3\%) tidak setuju. Sehingga terlihat responden kurang setuju jika mereka tidak akan beralih dari produk Zoya. Responden kurang setuju karena mereka menjelaskan mereka akan membeli produk selain Zoya jika produk lain memiliki ketentuan yang mereka inginkan, tipe konsumen seperti berikut disebut complex buying behavior dimana konsumen telah sadar bahwa merek mempunyai perbedaan-perbedaan yang jelas. Sehingga antara konsumen dan produk memiliki keterikatan yang sangat tinggi dalam melakukan pembelian, biasanya konsumen ini tidak terlalu banyak tahu mengenai kategori produk (Simamora, 2008: 23). Selain itu, golongan konsumen ini disebut juga dengan switcher (price buyer) konsumen akan memperhatikan harga sebelum melakukan pembelian dan biasanya akan berpindah-pindah dari merek satu ke merek yang lain. Dengan hal tersebut, perusahaan Zoya harus menyusun strategi untuk menyampaikan keterangan kepada calon pembeli tentang atribut-atribut produk diantaranya pentingnya suatu kualitas, merek perusahaan dan atribut lainnya.

Berdasarkan data yang tampak sebanyak 0,62 (62\%) responden setuju, $0,13(13 \%)$ informan yang sangat setuju, kurang setuju sebesar 0,2 (20\%), informan yang tidak setuju 0,05 (5\%) dan sangat tak setuju (0\%). Sehingga dominasi setuju dan mereka menyarankan orang lain menggunakan produk Zoya. Hampir seluruh konsumen berpendapat positif terhadap Zoya. Semakin tinggi sifat kepercayaan, maka sekumpulan komponen terdukung dan akhirnya mendukung keseluruhan dari sikap tersebut (Simamora, 2003 : 14). Selain itu, karena kualitas yang diberikan Zoya bagus sehingga membuat konsumen puas, maka mereka bersedia mengajak yang lainnya untuk menggunakan produk Zoya.

Diperoleh hasil analisis 0,28 (28\%) responden setuju, 0,07 (7\%) sangat setuju, kurang setuju 0,53 (53\%), 0,1 (10\%) tidak setuju dan juga sangat tidak setuju 0,02 (2\%). Data tersebut menjelaskan bahwa responden kurang setuju jika mereka akan membayar mahal untuk membeli Zoya dengan persentase 53\%. Hal ini berdasarkan karakteristik responden yang rata-rata mempunyai pekerjaan sebagai pelajar dan IRT yang berpendapatan $<$ Rp. 1.000.000,00 maka responden akan cenderung mengatakan kurang setuju karena mereka belum punya penghasilan sendiri dengan anggaran yang besar.

Didapatkan hasil analisis 0,38 (38\%) setuju, 0,07 (7\%) sangat setuju, pelapor kurang setuju 0,43 (43\%), 0,1 (10\%) pelapor tidak setuju dan 0,02 (2\%) pelapor yang sangat tidak setuju. Angka itu memperlihatkan responden kurang setuju 
jika mereka mengenali masalah sebelum membeli dengan bagian sebesar 43\%. Responden yang mengisi daftar pernyataan sebagian besar menjawab mereka setuju dengan mengenali masalah sebelum membeli produk Zoya karena responden tidak mau merasa kecewa setelah melakukan pembelian, yang akhirnya tidak setara dengan yang diharapkan. Pada bagian pengenalan masalah, prosesnya dimulai saat seorang pembeli sadar adanya kebutuhan. Kebutuhan tersebut muncul disebabkan adanya pengaruh internal maupun pengaruh eksternal (Simamora, 2008: 16). Beberapa responden kurang setuju jika mereka harus mengenali masalah terlebih dahulu, konsumen tersebut mempunyai keterlibatan rendah dengan merek dan cenderung kurang mencari informasi, biasanya konsumen akan langsung membeli produk yang diinginkan secara spontan tanpa harus mengutip informasi terlebih dahulu.

Sesuai analisis data diperoleh 0,13 (13\%) responden sangat setuju, 0,6 (60\%) setuju, kurang setuju 0,25 (25\%), tidak setuju 0,02 (2\%) dan sangat tidak setuju (0\%). Pehitungan data tersebut terlihat jelas bahwa konsumen setuju atas pernyataan saya mencari informasi terlebih dulu sebelum membeli Zoya dengan persentase $60 \%$. Mereka menyadari bahwa pencarian informasi produk sebelum melakukan pembelian sangat penting. Menurut jenis tingkatannya, konsumen berikut disebut pencarian informasi yang aktif, dimana konsumen akan menjalankan pencarian informasi dari berbagai sumber, dalam hal ini, seorang pembeli akan menggali informasi sebanyak banyaknya mengenai produk Zoya, dengan mencari informasi lewat web atau bertanya kepada teman terdekat mapun kerabat yang sudah menggunakan produk Zoya. Selain orang yang setuju, ada beberapa responden kurang setuju mengenai pendapat tersebut, menurut tingkatannya termasuk konsumen perhatian yang meningkat, dimana seorang konsumen mencari informasi yang biasa saja, dia merasa cukup puas mendapat informasi dari satu sumber saja, misalnya hanya mendapat informasi bahwa produknya mempunyai kualitas bagus, tanpa mencari informasi lain konsumen langsung membeli produk tersebut (Simamora, 2008: 16).

Dihasilkan dari analisis data 0,53 (53\%) responden kurang setuju, 0,35 (35\%) setuju, sangat setuju 0,02 (2\%), sangat tidak setuju (0\%) dan 0,1 (10\%) tidak setuju. Sehingga disimpulkan responden kurang setuju jika mereka mengenal produk Zoya melalui media massa dengan bagian sebesar 53\%. Sebagian responden kurang setuju karena mereka mengenal Zoya dari teman dan keluarga yang sudah lebih awal menggunakan produk Zoya, anggota keluarga mempunyai pengaruh yang kuat terhadap terhadap seseorang calon pembeli, mereka merekomendasikan untuk menggunakan produk tersebut (Simamora, 2008: 9). Selain itu, beberapa orang setuju dengan merek Zoya dikenali dari media massa, karena Zoya adalah merek yang dipercaya mensponsori sejumlah program film sebagai tumpuan busana dan make-up, diantaranya seperti: "Eat Bulaga Indonesia", "Kukejar Cinta ke Negeri Cina", "Assalamualaikum Beijing", "Mak Ijah Ingin Naik Haji", "Hijrah Cinta" dan "The Comment". Hal itu menjadi alasan bagi responden yang setuju bahwa mereka mengenal Zoya lewat media massa.

Berdasarkan analisis diperoleh 0,43 (43\%) responden setuju, 0,05 (5\%) sangat setuju, kurang setuju 0,4 (40\%), tidak setuju 0,1 (10\%) dan 0,02 (2\%) sangat tidak setuju. Sehingga informan setuju mereka membandingkan kualitas Zoya dengan produk lain sebelum melakukan pembelian dengan persentase $43 \%$. Seorang responden lebih dulu melakukan perbandingan antara merek Zoya dengan merek yang lain, perbandingan ini dijalankan agar responden bisa mengetahui apakah produk Zoya lebih bagus atau sebaliknya dibandingkan dengan busana muslim lain. Selain itu, responden selalu mencari kegunaan 
tertentu yang selanjutnya akan melihat atribut pada suatu produk, model konsumen ini disebut juga dissonance reducing buying behavior atau mengurangi ketidakcocokan dimana keterlibatan seorang pembeli mempunyai tingkat yang tinggi, sehingga sadar akan adanya perbedaan merek-merek yang jelas. Dalam hal ini berikut beberapa tahap seorang konsumen mengevaluasi barang yang akan dibeli, pertama seorang akan membeli busana muslim, satu stel baju muslim yang tergolong dari beberapa atribut dan akan dilihat calon pembeli seperti: warna, bahan, corak, harga dan ukuran. Masing-masing keinginan dan kebutuhan calon pembeli berbeda dalam menilai karakter apa yang paling penting, jika daya belinya tidak terbatas, kemungkinan seseorang akan memperhatikan kualitas sebagai faktor utama. Kedua seorang konsumen mengenai letak produk pada setiap atribut. Ketiga sejumlah kepercayaan tertentu disebut "brand image", misalnya kepercayaan akan produk Zoya yang berkualitas bagus, mutu terjamin dan beragam model yang disediakan. Keempat tingkat puas yang dirasakan konsumen terhadap produk yang beragam, jika seseorang menginginkan kualitas bahan, maka semakin bagus kualitas suatu bahan, kepuasan konsumen akan semakin besar dan kelima merupakan perilaku konsumen atas merek yang berbeda setelah melalui evaluasi. Keberadaan suatu merek lain yang mempunyai produk sama akan bersaing dan membuat konsumen merasa puas dengan produk yang diberikan, maka tugas seorang produsen adalah memperhatikan kebutuhan seorang konsumen melakukan survei atau penelitian mengenai kebutuhan seorang konsumen (Simamora, 2008: 1617 ; 23)

Sesuai hasil analisis didapatkan 0,6 (60\%) responden setuju, 0,17 (17\%) sangat setuju, kurang setuju 0,23 (23\%), $(0 \%)$ sangat tidak setuju dan $(0 \%)$ tidak setuju. Data tersebut menegaskan bahwa responden setuju mereka lebih dulu mempertimbangkan harga Zoya sebelum membeli dengan persentase 60\%. Konsumen berikut disebut dengan switcer dan berada ditingkatan pertama atau dasar dalam piramida loyalitas dimana seorang pembeli tidak tertarik dengan produk yang ditawarkan, merek mendapatkan posisi kecil dalam pembelian keputusan (Rangkuti, 2002: 61). Jika dillihat dari karakteristik pendapatan, mayoritas responden berpenghasilan dibawah $\mathrm{Rp}$. 1.000.000, hal tersebut merupakan alasan bahwa konsumen terlebih dahulu mempertimbangkan harga sebelum melakukan pembelian, akan tetapi karena konsumen ingin membeli produk merek Zoya, maka mereka mengumpulkan uang, jika uang sudah cukup dan terkumpul mereka akan membelanjakan uangnya untuk membeli Zoya.

Berdasarkan analisis data didapatkan 0,25 (25\%) konsumen setuju, 0,15 (15\%) sangat setuju, kurang setuju 0,5 (50\%), 0,07 (7\%) tidak setuju dan 0,03 (3\%) sangat tidak setuju. Data tersebut terlihat jelas responden kurang setuju jika mereka membeli produk Zoya setelah mendapatkan informasi yang cukup dengan persentase $50 \%$. Hal yang demikian terjadi pada saat seseorang mengambil keputusan membeli produk Zoya responden tidak mendapat informasi yang cukup. Beberapa responden membeli produk Zoya tanpa sengaja dan langsung membeli, selain itu beberapa responden sengaja mencari untuk padanan baju, jadi tidak semua responden membeli produk Zoya setelah mendapatkan cukup informasi. Tipe konsumen jenis ini disebut juga dengan variety seeking buying behavior atau perilaku seorang yang mencari keberagaman dimana konsumen mencari keragaman bukan kepuasan, dalam tipe ini sebuah merek tidak menjadi hal mutlak. Sebagai produsen, upaya yang harus dilakukan untuk tipe pelanggan seperti ini adalah menyediakan banyak stok dan membuat promosi-promosi agar konsumen lebih tertarik untuk membeli. Jika tidak, maka konsumen akan berganti ke merek lainnya. 
Berdasarkan analisis data diperoleh 0,3 (30\%) responden sangat setuju, 0,6 (60\%) setuju, kurang setuju 0,1 (10\%), tidak setuju $(0 \%)$ dan sangat tidak setuju $(0 \%)$. Hasil wawancara menunjukan bahwa konsumen setuju bahwa Zoya sesuai dengan yang diharapkan. Kepuasan seorang pelanggan terhadap produk yang mereka pakai adalah hal-hal yang harus diutamakan oleh produsen, begitupun dengan pelanggan yang menggunakan produk Zoya, mereka merasa senang dengan produk Zoya, karena sama dengan yang diharapkan, baik kualitas, pelayanan maupun atribut-atribut lain pada produk Zoya. Pelanggan berdasarkan penjualan pembelian dibagi menjadi dua, diantaranya pelanggan ulang dan baru, pelanggan baru merupakan seorang yang membeli secara perdana produk tertentu sedangkan pelanggan ulang yaitu pelanggan yang pernah membeli barang dan mereka merasa puas sehingga membeli lagi produk tersebut. Jika seorang pelanggan tidak mendapatkan tingkat kepuasan sesuai permintaannya, maka dia akan melakukan hal sebaliknya bahkan akan menyampaikan rasa tidak puasnya kepada individu lain. Untuk mengantisipasi hal tersebut produsen harus menggunakan alat komunikasi purna beli, dimana konsumen bisa menambahkan saran dan kritik dan dengan cara mengirimkan surat atau perusahaan menyediakan layanan konsumen.

\section{KESIMPULAN DAN IMPLIKASI}

Berdasarkan keseluruhan rangkaian penelitian yang selesai dilakukan terkait loyalitas merek dan kesan kualitas terhadap langkah konsumen mangambil keputusan membeli produk Zoya, maka kesimpulannya yaitu responden lebih memilih kesan kualitas dari pada loyalitas dalam penngambilan keputusan membeli produk Zoya. Hal ini dapat dibuktikan dengan jawaban angket yang disebar, sejumlah besar responden menanggapi setuju kesan kualitas Zoya sangat berperan dalam pengambilan keputusan. Mulai dari material, ciri khusus, motif, warna dan pelayanan menjadi komponen dari kualitas Zoya, nilai rata-rata yang didapat sebesar 57\%. Sedangkan loyalitas merek mempunyai nilai rata-rata $54 \%$ yang meliputi perbandingan produk, pembelian ulang, tidak beralih ke produk lain, merekomendasikan orang lain menggunakan Zoya dan membayar produk Zoya dengan mahal.

Terdapat beberapa implikasi pada penelitian ini, diantaranya:

1. Kualitas produk Zoya menjadi alasan konsumen melaksanakan pembelian. Kesan kualitas tersebut meliputi atribut-atribut beragam, seperti material, warna dan motif yang digunakan produk Zoya tidak dimiliki produk lain termasuk pelayanan yang ramah saat konsumen melakukan pembelian, oleh karenanya disarankan kepada pihak Zoya untuk mempertahankan kualitas

2. Kepada pihak Zoya untuk dapat mempertahankan konsumen agar tetap membeli dan mengenakan produk Zoya, perusahaan Zoya harus dapat menunjukan kepada konsumen meengenai keterjaminan kualitas produk Zoya

\section{DAFTAR PUSTAKA}

Anam, Choiril. 2014. Persepsi Penghafal AlQuran Terhadap Perbankan Syariah (Studi pada Pondok Pesantren Lembaga Kaderisasi Imam dan Dai Wadi Mubarak Bogor). Universitas Djuanda.

Arikunto, Suharsimi. 2010. Prosedur Penelitian; Suatu pendekatan praktek. Jakarta: Rineka Cipta.

Indrawati, D. (2015). Pengaruh Citra merek dan Gaya Hidup Hedonis Terhadap Keputusan Pembelian Jilbab Zoya. Riset Ekonomi dan Manjemen, Volume 15, No. 2,305 .

Margono. 2004. Metodologi Penelitian Pendidikan. Jakarta: Rineka Cipta.

Muzaqqi, Alim; Fauzi, Achmad dan Sutadi, Imam. (2016). Pengaruh Kesadaran 
Merek, Kesan Kualitas, Asosiasi Merek dan Loyalitas Merek terhadap Ekuitas Merek. Administrasi Bisnis, Volume 31, No. 31.

Nujulia. (2013). Pengaruh Brand Equity Terhadap Keputusan Pembelian Konsumen Pada Produk Pasta GIgi Pepsodent. Mahasiswa Pendidikan Ekonomi, Vol 2, No. 2.

Pradipta, D., Hidayat, K., \& Sunarti. (2016). Pengaruh Brand Equity Terhadap Keputusan Pembelian (Survei pada Konsumen Pembeli dan Pengguna Kartu Perdana Simpati Telkomsel di Lingkungan Mahasiswa Jurusan Administrasi Bisnis Angkatan 2012 \& 2013 Fakultas Ilmu Administrasi Universitas Brawijaya Malang). Administrasi Bisnis, 34, No. 1, 138-147.

Purnawa, Yuda. 2014. Pengaruh Aktivitas Media Twitter Bri Syariah Terhadap Kepuasan Nasabah Bri Syariah. Universitas Djunda Bogor.

Rangkuti, Freddy. 2002. The Power of Brands Teknik Mengelola Brand Equity dan Strategi Pengembangan merek + Analisis Kasus dengan SPSS. Jakarta; Gramedia Pustaka Utama.
Setyawan, Dodiet Aditya. 2013. Distribusi frekuensi. Surakarta: Poltekes Kemenkes.

Simamora, Bilson. 2003. Memenangkan Pasar dengan Pemasara Efektif dan Profitabel. Jakarta: PT Gramedia Pustaka Utama.

Simamora, Bilson. 2008. Panduan Riset Perilaku Konsumen. Jakarta: PT Gramedia Pustaka Utama.

Siti, Sofiah Neng. 2016. Pengaruh Nisbah Bagi Hasil Deposito Mudharabah Terhadap Loyalitas Nasabah (Studi BMT Berkah Mandiri Sejahtera). Universitas Djunada Bogor.

Sugiyono. 2014. Metode Penelitian Kuantitatif, Kualitatif dan R\&D. Bandung: Alfabeta.

Sunyoto, Danang 2014. Praktik Riset Perilaku Konsumen cetakan ke-1: Yogyakarta. Penerbit CAPS.

Qurniawan, Muhammad; Kusmaningrum dan Arijanto, Sugih. (2014). Pengukuran Brand Equity Kerudung Instan di $\mathrm{CV} \mathrm{X}$. Online Institut Tekhnologi Nasional, 02 No. 1, 378-388. 